DOI: https://doi.org/10.31933/dijemss.v3i2

Received: 20 November 2021, Revised: 20 December 2021, Publish: 18 January 2022

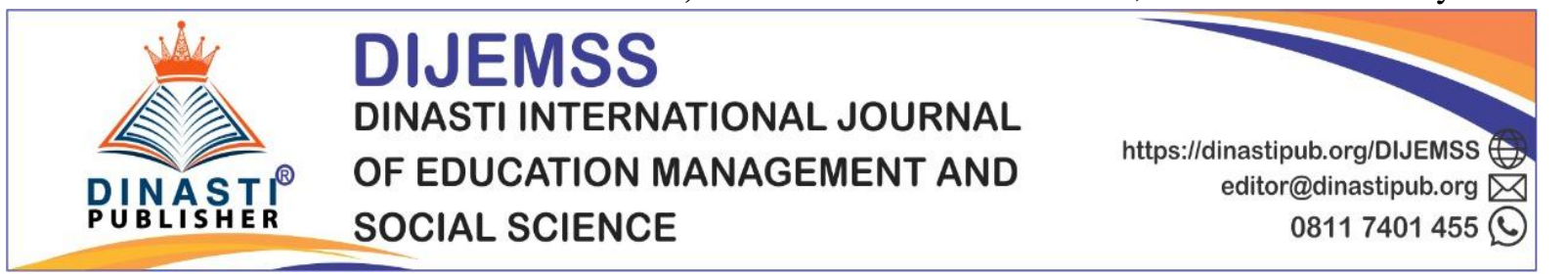

\title{
WOMEN'S ENTREPRENEURSHIP AND IMPLEMENTATION OF MARKET ORIENTATION MODEL TO IMPROVE BUSINESS PERFORMANCE OF SMES BATIK JAMBI
}

\author{
${ }^{1}$ Ade Octavia, ${ }^{2}$ Zulfanetti Zulfanetti, ${ }^{3}$ Yayuk Sriayudha, ${ }^{4}$ Heriberta Heriberta \\ 1) Faculty Economic and Business, Universitas Jambi, yayuk.sriayudha@unja.ac.id \\ ${ }^{2)}$ Faculty Economic and Business, Universitas Jambi \\ ${ }^{3)}$ Faculty Economic and Business, Universitas Jambi \\ ${ }^{4)}$ Faculty Economic and Business, Universitas Jambi
}

\section{Corresponding Author: Ade Octavia}

\begin{abstract}
Investigating of market orientation relationships and business performance has been widely conducted, but the research related to the implementation of the market-business performance orientation model is still relatively rarely. A woman entrepreneur who accepts challenging roles to meet her personal needs and become economically independent is an important role in economic independence. The research aims to analyze how the role of women entrepreneurs in applying market orientation models to improve business performance in SMEs of Batik Jambi in Jambi City. The method used in this study is qualitative method. The results of this study found that SMEs batik Jambi is mostly owned and managed by women entrepreneurs. They have been market oriented and impacted on business performance. Orientation to consumers is a strength factor for women to run their business and they tend to be more responsive to what competitors do. This study found that women entrepreneurs have the ability to coordinate internally. This becomes an internal force for SMEs to improve business performance as well. Lack of the competence in tecnology and information is one of women deficiency that need to be develpo in order to gain competitive advantage among them.
\end{abstract}

Keywords: women's entrepreneurship, consumer orientation, competitor orientation, internal coordination, business performance.

\section{INTRODUCTION}

\section{Statement of The Problem}

The development of market orientation models for small and medium enterprises (SMEs) through empirical testing has been widely done, the results show that market orientation is very important for improving business performance. The orientation of the market and the business environment has a positive relationship to the business performance 
of SMEs (Ndubisi \& Agarwal, 2014), where the external environment as a moderator of the relationship between corporate entrepreneurship and business performance. Especially for newly established companies, the entrepreneurial environment has an influence on business performance through entrepreneurial networks of resource acquisition and interfunctional coordination (Octavia et al., 2017). (Okeyo et al., 2014) strengthen the business environment relationship model, market orientation and business performance. Market orientation influences the performance of SME businesses through the business environment. (Octavia \& Ali, 2017) stated that consumer orientation is an antecedent of business performance, although orientation has no direct effect on business performance. That is, although other studies explained a positive relationship between market orientation and business performance, but for SMEs itself the relationship is precisely indirectly through consumer orientation. Strengthening is needed in SMEs to understand some more variables. Octavia et al 2017 (Octavia \& Sriayudha., 2017) conducted empirical testing of entrepreneurial training relationships, entrepreneurial orientation, market orientation and business performance. To improve the business performance of market-oriented SMEs is very necessary indeed. But it is also necessary to improve the ability of SMEs through mentoring and training to gain entrepreneurship-oriented. Surely the model that has been found and has been done empirical testing needs to be applied to SMEs through managerial aspects. The application of this model will be compiled or formulated into a strategy formulation and ready to be applied to SMEs batik Jambi.

Batik Jambi industry is the focus of research because the industry is dominated by women entrepreneurs. Batik is one of the traditional Indonesian crafts that has been worldwide. Batik Jambi is a characteristic of Jambi culture and also known to have unique patterns and motifs. More than $90 \%$ of SMEs of Batik Jambi are managed by women. The role of women in entrepreneurship contributes to economic development and prosperity (Agarwal \& Agarwal, 2018; Kelley et al., 2017; Nichter \& Goldmark, 2020). Women are considered successful in entrepreneurship because they have the ability to control and build relationships with partners while male entrepreneurs are successful if they have found their end goal. Some of the things that play a role in the success of women entrepreneurs include the ability to stand independenly, to be able to face risks, to overcome high competitiveness, to have an innovation orientation and strategic plan (Agarwal \& Agarwal, 2018; Doss, 2013). Through entrepreneurship, women eager to achieve their goals to be recognized by the environment. Identity and recognition of women will also bring happiness to theirselves personally. (Wolf \& Frese, 2018) observe that for women entrepreneurs, there are several factors related to family that need to be considered. Couples who provide practical support, share advice or ideas, expand their network of entrepreneurs, encourage and entertain them in difficult times, or provide directly a positive influence on entrepreneurial outcomes. At the same time, if a spouse in the family burdens their partner with domestic affairs responsibilities or intervenes in their business it may have a negative influence for women to explore their own entrepreneurial outcomes. This study analyzed how the role of women's entrepreneurship in implementing market orientation models with the aim to improve the business performance of SME Batik Jambi. 


\section{Market Orientation and Business Performance of Batik Jambi.}

The prior research from Harris and Ogbonna (1999) focused on looking at the relationship between market orientation and organizational performance. The researcg sample used is 1000 different industrial units and belongs to the criteria of large and medium-sized companies. Market orientation is measured using Narver and Slater instruments (1990). While indicator performance measures are: consumer satisfaction, sales growth, market share, competitive advantage and sales volume. The results showed that there is a significant relationship between market orientation and organizational performance. Asgar et.al (2013) conducted a test of the relationship between market orientation and business performance in small and medium-sized businesses. The results showed there was a positive and significant relationship between the market's orientation to business performance. This result is also in line with the findings of Baker and Sinkula (2009). Furthermore, researchers also tested the relationship between dimensions of market orientation to business performance. The results showed there was a significant positive relationship between customer orientation toward performance and interorganization of performance. There was no significant influence between competitors' orientations toward business performance, but the relationship was positive. The results of this study support the opinion that not all components of market orientation have a significant positive relationship to business performance (Ndubisi, 2015). Asikhia (Asikhia, 2010) stated that customer orientation as one of the dimensions of market orientation has a significant effect on business performance. There are moderating variables between customer orientation relationships and business performance i.e. management information systems and managerial attitudes. This research is in line with (Essmui et al., 2014), the business environment is an intervening variable between market orientation and business performance. The prior research also found that technology and competitive intensity are not moderation variables between market-business performance orientation relationships. Technology is a factor that influences business innovation. Renko et al (2009) stated that there is a positive relationship of business environment characteristics, competition priorities and value chain structure to superior business performance. This is in line with the research of (Ndubisi \& Agarwal, 2014) but the external environment as a moderator variable the relationship between corporate entrepreneurship and business performance. For newly established companies, the entrepreneurial environment has an influence on business performance through entrepreneurial networks and resource acquisition. Essmui's (2014) research found that there was no relationship between the level of competition companies faced and the level of sales. External environmental factors (market turmoil and competitive intensity) impact strategic focus. Furthermore, customer orientation and intercoordination affect the improvement of company performance. Khan and Quaddus (2015) conducted research on the informal business sector and found a significant influence between the business environment on socio-economic performance. They also described that there is a relationship between the marketing environment and business performance directly. Market orientation and business performance relationships can be strengthened by networking, especially for small and medium-sized businesses that will enter the international market. 


\section{RESEARCH METHOD}

Consistent with the problems and objectives of the research, qualitative design is the most appropriate approach to getting answers to research problems. Qualitative approach uses a strategy analysis approach by scanning the internal and external environment of SMEs. Based on this scanning will be formulated the right strategy for improving the business performance of SMEs batik Jambi. Furthermore, the strategy will be implemented to SMEs batik Jambi through simulation and FGD approach together with the government and UKM batik Jambi. The role of UKM batik Jambi becomes a limited-scale unit for model testing. The subjects in the study were SMEs batik Jambi in The District of Pelayangan : (1) The owners of Batik Jambi Business as many as 3 people, (2) The employees of SMEs batik Jambi as many as 5 people, (3) Head of Cooperative And MSMEs Office of Jambi Province as many as 1 person, (4) Head of Women's Protection, Child Protection and Population Control Council in Jambi Province as many as 1 person and (5) Competitors and consumers of batik jambi each as many as 5 people. The respondent's profile can be viewed as follows:

Table 1. Socio-Demographics Profile

\begin{tabular}{|c|c|c|c|}
\hline No & \multicolumn{2}{|c|}{ Sociodemographics } & Frequency \\
\hline \multirow[t]{2}{*}{1} & \multirow[t]{2}{*}{ Gender } & Male & 4 \\
\hline & & Female & 16 \\
\hline \multirow[t]{3}{*}{2} & \multirow[t]{3}{*}{ Age (years old) } & $17-25$ & 5 \\
\hline & & $26-40$ & 8 \\
\hline & & $>40$ & 7 \\
\hline \multirow[t]{2}{*}{3} & \multirow[t]{2}{*}{ Educational Background } & High School Graduate & 15 \\
\hline & & Bachelor Degree & 5 \\
\hline
\end{tabular}

In the study, there are two carried out stages :

1. The Research Preparation Stage. Researchers create interview guidelines that contain fundamental questions according to the research problem. The guidelines of the next interview are discussed with several experts to get input on the contents of the guidelines. Some input about the content of the guidelines used for the improvement of interview guidelines will then be used as a basis in the implementation of the interview. In the stage of research preparation, observations are also carried out to find out the condition of the research subject and readiness for the time and place of the interview.

2. The conduct of research is carried out after there is an agreement between the research subject and the researcher. The implementation of the research was conducted at the location of UKM batik Jambi n The District of Pelayangan, for the research subjects of the owners and employees of UKM batik Jambi. Meanwhile, the relevant service is carried out in their respective offices. Interviews to consumers of batik jambi were conducted in several places in Jambi City.

For data collecting, the techniques with observation methods was caried out and supported by interviews and properly documentation:

1) Observations are carried out directly at the location of UKM batik jambi to get a complete picture related to the focus of research. Observations are made on (a) SME activities in conducting businesses based on orientation to consumers, understanding of 
competitor reactions and application of business management, (b) the entrepreneurial orientation of women in managing batik jambi business, (c) observing the internal and external environment of SMEs batik jambi which has a direct and indirect effect on the performance of SMEs batik jambi and (d) the performance of SMEs batik Jambi. All observations are written as field notes containing routine, temporal, interaction and interpretation events.

2) Interview. Interview activities are conducted face-to-face, dialogue and direct Q\&A with the owners of SMEs batik jambi, employees batik jambi, related agencies, competitors and consumers. Interview results are written in a summary structure, situation description, data description and conclusion/ theme.

3) Documentation. The method of documentation, which is to look for data about things or variables in the form of notes, transkips, books, newspapers, inscriptions, meeting minutes, lengger, agenda, and so on. The documentation collected includes the results of research, reports and other publications in accordance with the focus of the research.

In conducting analysis and interpretation of the data used, the analytical tools used include:

temporal, interaction and interpretation

1) Data Reduction. All data from observations and interviews are made abstractions, discarded data that is not needed and organized data systematically so that meaningful conclusions are generated without eliminating data.

2) Presentation of data is carried out to reveal the overall narrative that describes women's entrepreneurship, market orientation, business environment and business performance of SMEs. The presentation of data is obtained from the reduction of data that has been done.

3) Conclusion and verification. Data that has been arranged is patterned, focused and arranged systematically so that the meaning of data can be generated. It will then be combined with other data sources. In a way

a. Perform an analysis of the internal environment used by resource-based view (RBV). This model uses an above average return approach that is largely determined by the characteristics within the company. Observations will be made related to the characteristics of UKM batik jambi by creating a profile and focus on the development or acquisition of resources / capabilities. Furthermore, an analysis of resources covering all financial, physical, human and corporate culture assets used by the company to develop, produce / create and offer products to the target market.

b. Analyze the external environment using PEST (political, economic, social and technology) methods. PEST analysis will help create a comprehensive and logical picture of the business environment of batik jambi from various aspects.

c. Formulate strategies based on internal and external environmental analysis. The strategy will be determined based on three main strategies: (1) Cost leadership strategy. This strategy will be used if the organization wants to become a low-cost market leader with a broad customer base, (2) Differentiation strategy will be 
used if the company wants to compete with its competitors in terms of the uniqueness of the products and services offered, (3) Focus strategy (cost-based or differentiation) will be used if the company wants to serve the specific needs of the niche market.

Data validity checks are carried out by triangulation methods (methods, data sources, and data collection tools). Examination of data by comparing data from different sources to anticipate lost data, in triangulating the data found in the study through observations and interviews between different groups is analyzed. There are five groups, namely the owners of SMEs batik jambi, employees of batik jambi, related agencies, competitors and consumers. Furthermore, the examination of validity is also carried out by means of discussion through limited group discussion (FGD). In this case FGD was conducted with participants from academia, the industrial world and government numbering 11 (eleven) people.

\section{FINDINGS AND DISCUSSION.}

\section{Externally Driven}

The study analyzed how the role of women's entrepreneurship in implementing market orientation models with the aim to improve the business performance of SME Batik Jambi. Economically the use of batik Jambi is now increasingly widespread. Moreover, the government has declared a national batik day on October 2. Batik Jambi products as one of the fashion products in the future will be increasingly in demand, even starting to be liked by teenagers and millennials. Batik is now present in people's daily lives. Batik not only has artistic value, cultural value but also has a bright business prospect value. Say Data from the Ministry of Industry and Trade recorded batik exports during 2018 reached Rp. 818.44 billion and will continue to grow mainly to Japan, America and some countries in Europe. Efforts to melestarian batik carried out by batik business people have many obstacles, many mainly related to human resources (Kusumasari, 2013). The owner of the batik jambi business stated that he growing market demand for batik models that are more varied makes it a challenge for batik jambi to always be innovative to develop it. People should have participated in various trainings conducted by local governments and universities. Other respondents said that Batik Jambi has a market that includes inside Jambi city and outside of Jambi city. It's product also has more durability compared to Javanese batik. Although Javanese batik is available more than Jambi batik but is offered in the market with different artificial qualities. Similarly, batik Jambi, so this result can not conclude the durability of a product is better compared to other products. Based on the perspective of Javanese batik consumers more have a more diverse pattern or model than Batik Jambi. One area in which differences between Jambi and Javanese batik is in the materials and techniques employed (Kerlogue, 2005). Consumer respondents said that when compared to Javanese batik and batik Jambi, then for the pattern indicator or model the value of Javanese batik is higher compared to Jambi batik. Various motif of batik Jambi are one of the preference for customer (Sriayudha \& Nifita, 2014).

Furthermore, Other consumer respondents stated that Javanese batik is actually also easy to order, but in a different way. Consumers should have complete information about the 
place of ordering Javanese batik. Moreover, every region in Java has this industry such as in Solo, Yogya, Cirebon, Semarang, Tuban and others. Based on history, the existence of other influences causes Javanese batik to be divided into two, namely, batik pedalam (Solo, Yogya) and coastal batik (Cirebon, Lasem, Madura, Tuban, and others) classification is based on the geographical indication environment (culture) and motif patterns. Coastal batik is essentially batik from outside the palace, free, without being bound to the natural standards of magical relegius mind, feudalism and technical institutions, coastal batik patterns are more spontaneous, rough and free both the pattern and color compared to batik from the palace. Batik Jambi is a development of Javanese batik. Based on history, the beginning of batik in jambi was brought by Javanese merchants. Furthermore, it was developed in Jambi specifically for the jambi nobles. Thus batik Jambi which is now developing is the result of the development of Javanese batik, but the judging is more of a motif or pattern. According to consumer respondents, batik Jambi tends to be easy to order because it is close to the location of respondents in Jambi City. These orders are made especially if the purchase is in bulk and the consumer wants certain motifs and colors that are not widely available in the market. Some respondents also stated that Delivery of Jambi batik is faster compared to Javanese batik, considering that the order is done close to the respondent's place. Batik delivery system is done through freight forwarding services, delivered directly by producers or craftsmen and so on. The current online ordering system is also an option that makes it easier for consumers to get products.

Batik is a cultural product so often consumers are interested in knowing more about the philosophy contained in it. The price of batik also varies depending on the quality of the material, the type of batik both write or stamp, size or color. Respondents said that Thus often consumers ask about it to artisans or batik sellers. So that the seller / employee of the store is required to have knowledge about it. In this study, Jambi batik sellers were better able to consult with consumers compared to Javanese batik sellers. Today Batik Jambi has merged with people's lives, which can be seen with the increasing number of batik industries that are growing and becoming a Joint Business Group or center. Currently the number of Jambi batik artisans in Jambi City itself amounts to 102 business units and has absorbed a workforce of 1100 people with a production value of Rp. 6,661.7 billion. Currently in Jambi Province there are more than 1,500 batik artisans with more than 100 batik entrepreneurs. About 80 percent of them are in Jambi City. But of the overall artisans and batik businesses only a few set the foreign market as a target market. In fact, as a product of native Indonesian culture, batik crafts have uniqueness and characteristics that can be offered abroad. Compared to batik that comes from central Java (especially Pekalongan), Jambi batik is still left behind. Both judging from the factors of production, expertise and creativity, sales level, the number of enthusiasts even to penetrate into foreign markets. Many factors must be prepared, from the role of the government to the internal and external marketing environment of batik business itself. According to respoden the owner of UKM batik Jambi:

Although national and international events have been followed to introduce Jambi batik among business people and consumers at home and abroad, the impact has not been 
significantly seen for the development of Jambi batik business and the increase in market share.

Globalization is making Chinese and Indian printed textiles cheaper and able to overtake a market once dominated by handmade batik crafts worked by human labor (Poon, 2020). It should be underlined that the export market provides promising opportunities. Based on the data, there was an increase in batik exports by $36.46 \%$ which means that there is considerable demand for foreign markets for batik. The problem is, many batik entrepreneurs, especially Batik Jambi who have not been encouraged to direct their marketing strategies to foreign markets. According to respondents from the relevant departments said that In the current era of globalization and free trade it is not impossible to penetrate foreign markets. With the right strategy, strong business capabilities and support from the government, directing Jambi batik products to foreign markets can be done.Other relevant service respondents analyzed that It needs a strong motivation from SMEs to be market oriented especially to the global market. Although the opportunity for export was wide open and the government gave a boost to enter the export market.

\section{Internally Driven}

Javanese batik has more special outlets selling batik compared to Batik Jambi. This of course should be a concern, because in the batik producing area itself there are still few special outlets of Jambi batik sellers. Based on observations, Javanese batik is more scattered especially for the type of apparel that can almost be found in some places. Jambi batik special outlet itself there is very limited. Thus, it must be encouraged again the opening of outlets or stores of Jambi batik sellers to make it easier for consumers to find the product. Javanese batik is easier to find in many places compared to Jambi batik. According to the consumer It is difficult to find Jambi batik in malls or shopping centers or in public stores, Jambi batik is only available in special outlets or at jambi batik making centers. Other respondents argued that online purchases are sometimes made by consumers to make it easier for them (Oberoi et al., 2017). Obviously, Javanese batik is easier to find in online shopping sites thant Batik Jambi. But, from the diversity of products and designs of Batik Jambi is able to compete with Javanese batik. However, in terms of mastery of technology Javanese batik entrepreneurs are more masterful compared to Jambi batik entrepreneurs. Thus, it is necessary to increase the ability to master technology, especially the internet for Jambi batik entrepreneurs to be able to take maximum business opportunities through online marketing systems. Batik is historically the result of domestic work. Batik is basically a craft that doomsminated women's skills i.e. the ability to handle canting and small copper containers (Santyaningtyas \& Noor, 2016). In term of color, Jambi batik color is brighter and more interesting than Javanese batik. Batik Jambi often uses bright colors such as red, orange, blue and green. The use of natural ingredients from plants as dyes makes the results look natural and illustrates the nuances of nature. As sepang wood produces a reddish yellow color, ramelang wood produces a brownish red color, slow wood produces yellow and tilapia wood produces blue. The patterns in Batik Jambi may be the embodiment of infinite Islamic concepts and framed with patterns with local beliefs. Some batik artisans in Jambi still use natural dyes, with the aim that the color of batik is not easily worn. The natural dye comes 
from plants that only exist in jambi province. These colors are the traditional colors of Jambi batik, which has a distinctive charm that is different from chemical dyes. One og thr owner of UKM batik Jambi stated that Batik Jambi has a distinctive motif in the form of flora and fauna in jambi. Interesting colors such as red, yellow, green, blue and other bright colors. Other respondents claimed that the design and motif of Batik Jambi is mostly taken from the form of flora and fauna. The uniqueness of Jambi batik lies in the simplicity of the motif form that is a stand-alone motif form.

Another uniqueness is the name on the Motif Batik Jambi given to every form of motif, such as bungo tanjung motif, jasmine flower motif, cheerful motif and so on. Although the name is given to each form of motif consisting of one form but in its application does not consist of one form of motif only. At first the motifs applied by Batik Jambi in the form of ornamental motifs such as seen in the carving of jambi traditional houses and on wedding clothes. Today the resulting motifs are more diverse and rich in local cultural philosophy.

seller's knowledge about the quality of batik products sold is quite good, although according to consumers Javanese batik sellers have more knowledge about the quality of batik compared to Jambi batik sellers. Generally consumers will ask about the basic materials used, whether it is easy to fade or not, the quality of the stitches and how long usually the product is still in good condition. Usually the basic material of fabric used by batik craftsmen in the form of silk, cotton, pineapple fiber, shantung and parsimony.The friendliness and courtesy of batik sellers when providing explanations about the quality and type of products that consumers want is also a value for customers. The value of consumer perception shows a small difference in value, although Javanese batik sellers are considered more friendly and polite in serving consumers.Furthermore, consumers assess that Jambi batik sellers are more responsive in serving consumers compared to Javanese batik sellers even though the difference value is small. The responsiveness of the seller is seen from an attitude that can quickly absorb what the customer needs, for example asking what product to look for, helping to show the location of the product display and providing design and color alternatives that can be chosen by consumers. For consumers this responsive attitude is very helpful for consumers to find products quickly.

Implementation of strategy.

1. Operational Excellence

Batik Jambi has the advantages in terms of color and motif. As a development of Jambi culture, Jambi batik motifs have unique differences and become characteristic of the Jambi people. The existence of Jambi batik can be an introduction to jambi regional culture as an embodiment of the local wisdom of flora and fauna that dominates the motifs in Jambi batik. Thus strengthening on the promotion of Batik Jambi to other regions and countries is needed. This promotion will not only be able to improve the 
image of Jambi in the eyes of other regions or countries, but the impact will also be felt by Jambi batik artisans.

2. Costumer intimacy

Perception is the process by which a person selects, organizes and interprets information. When consumers gather information about high-engagement products, they will follow hirarkhi effects. Exposure to a piece of information such as an advertisement or information from a friend, attracting attention, then understanding and eventually retention in memory. Once consumers have fully perceived information, they use it to evaluate alternative brands and decide which ones to buy. The perception process is different for products with low levels of ability. Here consumers store information in their memory without going through the stages of attention and conversation. Exposure can cause consumers to retain enough information that they are familiar with a brand when they see it in the store.

3. Product leadership

From the image variable, Jambi batik is superior to Javanese batik, while Javanese batik has a higher value for variable products, services, personnel and distriBusi channels. This is an implication that consumers do not see too much of the fundamental difference between Jambi batik and Javanese batik, making it difficult for Jambi batik to position Jambi batik into something different. Batik has become synonymous Javanese products even become a symbol of the nation's culture. Long before the Jambi area and other areas moved its batik industry, Javanese batik was famous everywhere. Merepositioning Batik Jambi still requires strengthening on what aspects consumers think have distinctive differences with Javanese batik.

\section{CONCLUSION.}

Batik Jambi has the advantages in terms of color and motif. As a development of Jambi culture, the uniqueness differences of Jambi batik become characteristic of the Jambi people. The existence of Jambi batik can be introduce to jambi regional culture as an embodiment of the local wisdom of flora and fauna that dominates the motifs in Jambi batik. This difference in perception suggests that the same marketing strategies and elements cannot be used to market products/services with high engagement versus low engagement. Batik entrepreneurs should strive to increase consumer engagement with their products as a way to increase their revenue.

\section{ACKNOWLEDMENTS}

We would say thank you to Universitas Jambi, which has funded this research and a lot of thank you to all respondents who has given information related to the study.

\section{BIBLIOGRAPHY}

Agarwal, S., \& Agarwal, V. (2018). Motivational and success factors: Through the lens of women entrepreneurship Motivational and success factors: through the lens of women entrepreneurship Sucheta Agarwal * and Vivek Agrawal. January. 
https://doi.org/10.1504/IJMED.2018.096231

Asikhia, O. (2010). Customer Orientation and Firm Performance among Nigerian Small and Medium Scale Businesses. International Journal of Marketing Studies, 2(1), 197-212. https://doi.org/10.5539/ijms.v2n1p197

Doss, C. (2013). Intrahousehold Bargaining and Resource Allocation in Developing Countries 1. 52-78. https://doi.org/10.1093/wbro/lkt001

Essmui, H., Berma, M., Shahadan, F. B., Ramlee, S. B., \& Bin, M. F. (2014). Structural Equation Model for Analyzing the Impact of Business Environment on Firm 's Growth. 6(9), 177-189. https://doi.org/10.5539/ijef.v6n9p177

Kelley, D. J., Baumer, B. S., Brush, C., Greene, P. G., Mahdavi, M., Majbouri, M., Cole, M.,

Dean, M., \& Heavlow, R. (2017). Global Entrepreneurship Monitor Women's Entrepreneurship 2016 / 2017 Report Global Entrepreneurship Monitor 2016 / 2017 Report on Women's Entrepreneurship.

Kerlogue, F. (2005). Jambi batik: A Malay tradition? Indonesia and the Malay World, 33(96), 183-204. https://doi.org/10.1080/13639810500283613

Kusumasari, D. (2013). Business Preservation of Batik Indonesia ( Heritage ), Challenges and The Solution. Jurnal Ilmu Manajemen \& Ekonomika, 12(1), 9-14.

Ndubisi, N. O. (2015). Relationship marketing and customer loyalty. May. https://doi.org/10.1108/02634500710722425

Ndubisi, N. O., \& Agarwal, J. (2014). Quality performance of SMEs in a developing economy: Direct and indirect effects of service innovation and entrepreneurial orientation. Journal of Business and Industrial Marketing, 29(6), 454-468. https://doi.org/10.1108/JBIM-07-2013-0146

Nichter, S., \& Goldmark, L. (2020). Small Firm Growth in Developing Countries Small Firm Growth in Developing Countries. World Development, 37(9), 1453-1464. https://doi.org/10.1016/j.worlddev.2009.01.013

Oberoi, P., Patel, C., \& Haon, C. (2017). Technology sourcing for website personalization and social media marketing: A study of e-retailing industry. Journal of Business Research, 80(June), 10-23. https://doi.org/10.1016/j.jbusres.2017.06.005

Octavia, A., \& Ali, H. (2017). International Review of Management and Marketing The Model of Market Orientation, Entrepreneurial Orientation and Business Performance of Small and Medium Enterprises. International Review of Management and Marketing, 7(3), 331-337. http:www.econjournals.com

Octavia, A., Zulfanetti, \& Erida. (2017). Influence models of entrepreneurial orientation, entrepreneurship training, and business performance of small medium enterprises. Advanced Science Letters, 23(8), 7232-7234. https://doi.org/10.1166/asl.2017.9338

Okeyo, W. O., Gathungu, J., Cps, K., \& Obonyo, P. P. K. (2014). The Effect of Business Development Services on Performance of Small and Medium Manufacturing Enterprises in Kenya. International Journal of Business and Social Research, 4(6), 12-26. https://doi.org/10.18533/ijbsr.v4i6.536

Poon, S. (2020). Symbolic Resistance: Tradition in Batik Transitions Sustain Beauty, Cultural Heritage and Status in the Era of Modernity. World Journal of Social Science, 7(2), 1. https://doi.org/10.5430/wjss.v7n2p1 
Santyaningtyas, A. C., \& Noor, M. Z. M. (2016). Preserving of traditional culture expression in Indonesia. Asian Social Science, 12(7), 59-65. https://doi.org/10.5539/ass.v12n7p59

Octavia, A \& Sriayudha, Y (2017). LINGKUNGAN BISNIS DAN KINERJA UKM BATIK JAMBI. Jurusan Manajemen Fakultas Ekonomi dan Bisnis Universitas Jambi email: octavia@unja.ac.id.2010,27-28.

Sriayudha, Y., \& Nifita, A. T. (2014). Analysis of Preferences and Consumer Behavior of Batik Jambi. 28-34.

Wolf, K., \& Frese, M. (2018). Why husbands matter: Review of spousal influence on women entrepreneurship in sub-Saharan Africa. Africa Journal of Management, 4(1), 1-32. https://doi.org/10.1080/23322373.2018.1428019 